\title{
Relationship of milking traits and somatic cell count with electrical conductivity of goat milk during different milking phases
}

\author{
Birutè Šlyžienė*, Lina Anskienè, Evaldas Šlyžius, Vida Juozaitiené
}

\begin{abstract}
Lithuanian University of Health Sciences, Department of Animal Breeding, Tilžès street 18, Kaunas, Lithuania ${ }^{*}$ Corresponding author: birute.slyziene@gmail.com
\end{abstract}

\section{Abstract}

The aim of this study was to estimate the relation between milking traits and somatic cell count with electrical conductivity of goat milk during different milking phases. The research was carried out in the herd of Czech White Shorthaired and Saanen goat breeds ( $n=323$ ) with the help of the electronic milk flow meter LactoCorder ${ }^{\oplus}$. The milk yield, milking duration, milking flow rate and electrical conductivity of milk in the different phases of milking showed the significant mean differences between the breeds. Almost all (except electrical conductivity during the initial time) investigated indicators of electrical conductivity had a significant positive correlation with SCC. The bimodality of milk flow was determined in $9.69 \%$ of goats and associated with milk yield decrease and SCC increase $(P<0.05)$. The results confirm that the milk flow curve data is a good tool to control milking traits of goats, to predict the prevalence of mastitis and, thus, to improve the health of the udder of goats.

Key words: goat, electrical conductivity, bimodality, milk flow curve 


\section{Introduction}

Goat milk production is a growing industry (Gautam et al., 2020) and is used to make products such as cheese or yoghurt, therefore it is essential to have high quality milk in order to produce quality products (Silanikove et al., 2010; Romero et al., 2012; Zazharska et al., 2018). There is an increasing demand for high quality goat milk, however, there is also one of the major problems - mastitis. It affects not only goat productivity and health but also the welfare of the animal. Mastitis in all its forms is the major factor that affects the impact of raw milk quality on finished dairy product quality and economic losses (Leitner et al., 2008; Romero et al., 2012). Intramammary infection is related to the increase in the somatic cell count in small ruminants (Zaninelli et al., 2015).

Somatic cell count and electrical conductivity are used in the diagnosis of mastitis (Morgante et al., 2000; Paape, 2000). Normal goat milk has a higher somatic cell count (700 000 to 1000000 cells $/ \mathrm{mL}$ ) than cow milk (Hinckley and Williams, 1981). Investigation of Yarabbi et al. (2014) in dairy cows showed that increase in the somatic cell count was associated with an increase of electrical conductivity $(P<0.05)$. Tangorra et al. (2010) found a significantly higher level of electrical conductivity in infected glands in different lactation stages.

The prevalence of mastitis in the goat population is influenced by genetic and non-genetic factors. Proper application and use of milking techniques on dairy goat farms can reduce the incidence of this disease. Milk yield and milk flow are important parameters, which should be evaluated and registered in goats (Borghese et al., 2013; Amin, 2020). Breed of dairy goats has an effect on milk yield (Guney et al., 2006; Norris et al., 2011). Kendall et al. (2009) estimated that the level of milk production depends on a breed, and there is variation in milk yield among different breeds and within the breed. Ying et al. (2004), in a study carried out with different breeds of goats, reported contradictory results: EC increased with infection in Saanen but decreased in Alpine goats. Diaz et al. (2011) estimated a significant correlation between electrical conductivity and milk yield in infected glands; analysing the data separately according to the health status of glands, the correlation was significant for infected glands, but no significant relations were estimated for other mastitis-free glands.

Therefore, early detection of mastitis should be an important management tool in goat farms (Romero et al., 2012; Zaninelli et al., 2015). However, estimation of electrical conductivity of goat milk is not broadly covered in the literature (Tangorra et al., 2010; Diaz et al., 2012). Since a reliable increase in electrical conductivity is established in milk of cows with mastitis, it must be possible to apply this indicator to establish mastitis in goats (Diaz et al., 2012).

Analysis of scientific literature has shown that there is a lack of data on goat milk flow rates at different phases of milking. The choice of publications on establishing electrical conductivity of goat milk is not very wide (Romero et al., 2012; Diaz et al., 2012). Moreover, there was no literature available on determining electrical conductivity of goat milk during different milking phases. The aim of this study was to estimate a relation between milking traits and somatic cell count with electrical conductivity of goat milk during different milking phases.

\section{Materials and methods}

The research was carried out in the herd of two goat breeds (Czech White Shorthaired, $n=230$, and Saanen, $n=93$ ) in Lithuania, at the State Enterprise Laboratory for Milk Control 'Pieno Tyrimai' and at the Department of Animal Breeding and Nutrition of Lithuanian University of Health Sciences. All investigated goats were raised in the same feeding and housing conditions. The animals were milked twice a day (7:00 a.m. and 6:00 p.m.). Milking parlor had a low-line design, self-locking gates and 2 platforms with 8 milking units and milking posts per platform. Milking parameters: a pulsation rate of 90 cycles/min, a vacuum level of $40 \mathrm{kPa}$ and a pulsation ratio of $60 \%$.

The 323 goats with lactation period of 2-4 months, on average of $3.3 \pm 0.09$ lactation were evaluated three times with the help of the electronic milk flow meter LactoCorder ${ }^{\circledR}$ (Lactocorder ${ }^{\oplus}$ WMB AG, Switzerland). LactoCorder ${ }^{\circledR}$ has been recognized as a measurement device by ICAR (International Committee for Animal Recording). The results of our measurements with LactoCorder ${ }^{\circledR}$ 
(http://www.lactocorder.ch) were processed by the software program pack LactoPro 5.2.0 (Biomelktechnik Swiss). A general description of investigated traits evaluated using LactoPro 5.2.0 program in this research:

/ MGG - Total milk yield (from the beginning to the end of the measurement), kg;

\section{/ Milking duration parameters}

/ tMGG - Duration of the total milking, min;

/ tMHG - Duration of the main milking phase, min;

\section{/ Milking flow rate parameters}

/ HMF - Highest milk flow rate in one minute, kg/ min;

/ DMHG - Average milk flow in the main milking phase, $\mathrm{kg} / \mathrm{min}$.

\section{/ Electrical conductivity parameters}

/ ELHMF - electrical conductivity at highest milk flow $(\mathrm{mS} / \mathrm{cm})$,

/ ELAP - electrical conductivity during the initial time $(\mathrm{mS} / \mathrm{cm})$ of milking (beginning peak level of the electrical conductivity),

/ ELAD - beginning peak difference of the electrical conductivity $(\mathrm{mS} / \mathrm{cm})$,

/ ELMAX - maximum electrical conductivity after reaching the highest milking speed $(\mathrm{mS} / \mathrm{cm})$,

/ ELST - step in the electrical conductivity $(\mathrm{mS} / \mathrm{cm})$,

/ ELND - level difference of the electrical conductivity ( $\mathrm{mS} / \mathrm{cm})$,

/ ELMNG - maximum electrical conductivity after main milking $(\mathrm{mS} / \mathrm{cm})$,

Bimodality of milk flow (BIMO) was detected when a curve had a flow pattern with 2 increments separated by a clear drop in milk flow for more than $200 \mathrm{~g} / \mathrm{min}$ within $1 \mathrm{~min}$ after the start of milking (Dzidic et al., 2004). Bimodality of milk flow was observed when it was repeated at least two milking's.

The research on the somatic cell count (SCC) in milk samples was performed at the State Enterprise Pieno Tyrimai. SCC in milk was determined using the measuring device Somascope (CA-3A4, 2004; Delta Instruments, the Netherlands), which operates on the principle of flow cytometry technology. State Enterprise Pieno Tyrimai operates under the quality management system conforming to the requirements of International Standard ISO/IEC 17025:2005 to ensure the accuracy of milk composition and quality tests.
Statistical characteristics in the sample (n) arithmetic mean (M), standard error (SE), P - value (P) - were calculated using IBM SPSS Statistics, version 20. Values SCC $(\times 1000$ cells $/ \mathrm{mL})$ were transformed into base 10 logarithm to normalize their distribution. Data analysis was performed by using Student's $t$ test. The relationship among the milking traits and SCC was determined using Pearson's correlation coefficient (r). The results were considered statistically significant when $P \leq 0.05$.

The research was conducted following the provisions of the Republic of Lithuania Law on the Care, Keeping and Use of Animals No 11-2271 of 03/10/2012 (Valstybès žinios (Official Gazette) 11010112 No 122- 6126 dated 20/10/2012) and other legal acts, and the Requirements for the keeping, care and use of animals used for scientific and training purposes No B1-866, dated 31/10/2012 (Valstybès žinios No 130-6595 dated 10/11/2012).

\section{Results and discussion}

The means and standard errors of total milk yield (MGG), total milking duration (tMGG), average milk flow in the main milking phase (DMHG), electrical conductivity at highest milk flow (ELHMF) and somatic cell count (SCC) in dairy goats used in this study were $1.511 \pm 0.045 \mathrm{~kg}, 2.965 \pm 0.099$ $\min , 0.634 \pm 0.014 \mathrm{~kg} / \mathrm{min}, 7.046 \pm 0.044 \mathrm{mS} / \mathrm{cm}$ and $6.123 \pm 0.032$, respectively.

Different goat breeds milk yield, milking duration and milking flow rate parameters are presented in Table 1. The Czech White Shorthaired breed showed on average a $0.217 \mathrm{~kg}$ higher total MGG per milking than Saanen breed $(P=0.023)$. By comparison with our results, Ciappesoni et al. (2004) reported similar Czech White Shorthaired goat breed milk production (3.09 kg/day). Boselli et al. (2009) reported means of milk yield per milking in Saanen goat breed from $1.63 \pm 0.04 \mathrm{~kg}$ (early lactation) to $0.67 \pm 0.05 \mathrm{~kg}$ (late lactation). Mioč et al. (2008) found that the Saanen breed had significantly $(\mathrm{P}<0.01)$ higher lactation and daily milk yield than the Alpine breed $(720 \mathrm{~kg}$ and $2.63 \mathrm{~kg} /$ day versus $577 \mathrm{~kg}$ and $2.08 \mathrm{~kg} /$ day, respectively). Conversely, Palhière et al. (2014) estimated a slight influence of the breed from $1012 \pm 212 \mathrm{~kg}$ (Alpine breed) to $994 \pm 237 \mathrm{~kg}$ (Saanen breed) per lactation. 
TABLE 1. Milk yield and milking traits in Czech White Shorthaired and Saanen dairy goats

\begin{tabular}{l|l|l|l}
\hline Parameters & Czech White Shorthaired & Saanen & $P$ \\
\hline MGG, kg & $1.555 \pm 0.053$ & $1.338 \pm 0.078$ & 0.023 \\
\hline tMGG, min & $3.156 \pm 0.115$ & $2.218 \pm 0.142$ & $<0.001$ \\
\hline TMHG, min & $2.590 \pm 0.109$ & $1.800 \pm 0.097$ & $<0.001$ \\
\hline HMF, kg/min & $0.857 \pm 0.019$ & $0.943 \pm 0.037$ & 0.040 \\
\hline DMHG, kg/min & $0.617 \pm 0.014$ & $0.703 \pm 0.035$ & 0.024 \\
\hline
\end{tabular}

TABLE 2. Electrical conductivity of milk from Czech White Shorthaired and Saanen dairy goats in different milking phases

\begin{tabular}{l|l|l|l}
\hline Parameters & Czech White Shorthaired & Saanen & $P$ \\
\hline ELAP & $7.236 \pm 0.106$ & $6.967 \pm 0.319$ & 0.425 \\
\hline ELAD & $0.298 \pm 0.029$ & $0.226 \pm 0.028$ & 0.077 \\
\hline ELMAX & $7.513 \pm 0.050$ & $7.656 \pm 0.089$ & 0.013 \\
\hline ELMNG & $3.880 \pm 0.203$ & $2.939 \pm 0.460$ & 0.050 \\
\hline ELHMF & $6.955 \pm 0.049$ & $7.402 \pm 0.086$ & $<0.001$ \\
\hline ELST & $0.731 \pm 0.067$ & $0.436 \pm 0.075$ & 0.003 \\
\hline ELND & $1.059 \pm 0.073$ & $0.692 \pm 0.094$ & 0.002 \\
\hline
\end{tabular}

The duration of the total milking (tMGG) and the duration of the main milking phase (tMHG) were also significantly higher $(\mathrm{P}<0.001)$ in Czech White Shorthaired breed in comparison to the Saanen breed (0.938 min and 0.79 min, respectively). Meanwhile the milking flow rate parameters were as follows: average milk flow in the main milking phase (DMHG) and maximum milk flow rate in one minute (HMF) were significantly higher in Saanen breed as compared to Czech White Shorthaired breed $0.086 \mathrm{~kg} / \mathrm{min}(\mathrm{P}=0.024)$ and $0.086 \mathrm{~kg} / \mathrm{min}$ $(\mathrm{P}=0.040)$, respectively. In comparison to our results, French scientists Palhière et al. (2014) have determined higher milking speed traits in the Alpine breed compared to the Saanen breed. In the course of the same research, the average milk flow during the main milking phase and the maximum milk flow per minute was $0.09 \mathrm{~kg} / \mathrm{min}$ and $0.12 \mathrm{~kg} / \mathrm{min}$ higher in Alpine breed, respectively. Boselli et al. (2009) reported higher means of maximum milk flow per minute in Saanen goat breed from $1.41 \pm$ $0.05 \mathrm{~kg} / \mathrm{min}$ (early lactation) to $0.92 \pm 0.05 \mathrm{~kg} / \mathrm{min}$ (late lactation) $(\mathrm{P}<0.001)$. Ilahi et al. (2000) noted the average milking speed of $1.095 \mathrm{~kg} / \mathrm{min}$ in Alpine goat breed. Bašić et al. (2009) determined higher means of total milking time from $2.48 \pm 0.10 \mathrm{~kg} / \mathrm{min}$ (third lactation) to $1.61 \pm 0.10 \mathrm{~kg} / \mathrm{min}$ (fourth lactation) $(\mathrm{P}<0.05)$ in the Alpine goats. The Spanish scientists Fernández et al. (2019) determined that by increasing the vacuum level from 42 to $44 \mathrm{kPa}$ milk flow significantly increased and the total milking time decreased by 25 seconds in Murciano-Granadina breed goats $(P<0.05)$. Zucali et al. (2019) examined the duration of the main milking phase in the Alpine goat breed and found that the highest values of peak flow and average milk flow were significantly affected by the vacuum level $(P<0.001)$.

The different goat breed averages of electrical conductivity are demonstrated in Table 2. The higher ELAP, ELAD, ELST, ELND, ELMNG were determined in Czech White Shorthaired breed (from 3.86 \% ELAP to $67.66 \%$ ELST). Meanwhile, ELMAX and ELHMF were significantly higher $(P<0.01)$ in the Saanen goat breed at $1.9 \%$ and $6.43 \%$, respectively. The effects of health condition, farm, lactation and stage of lactation are associated with EC (Diaz el al., 2011; Romero et al., 2012). The studies of Ying et al. (2004) in two breeds of goats 
demonstrated that the electrical conductivity in the Saanen breed of goats increased by $3.5 \%$, while in the Alpine goats this indicator decreased by $11.5 \%$ when comparing the milk of healthy goats and goats infected with mastitis. Romero et al. (2012) studied the Murciano-Granadina goats and determined $28.72 \%$ of EC as compared to our results. They reported $5.31 \mathrm{mS} / \mathrm{cm}$ mean of EC (from $5.07 \mathrm{mS} / \mathrm{cm}$ in primiparous goats to $5.45 \mathrm{mS} / \mathrm{cm}$ in multiparous goats $(\mathrm{P}<0.001)$.

For Czech White Shorthaired goats SCC had a significant positive correlation with almost all (except ELAP) investigated indicators of electrical conductivity (Table 3). For the Saanen breed, these correlations were equally reliable and higher (from 0.223 with ELAD to 0.406 with ELHMF). Similar results were reported by Diaz et al. (2012) determining a significant, moderate correlation between EC and SCC $(r=0.38, P<0.001)$ in the study with Murciano-Granadina goats. In the meantime, Ying et al. (2004) reported a lower correlation coefficient between electrical conductivity and SCC (0.089 and 0.056 in Saanen and Alpine goats, respectively).
Between milk yield and milking duration MGG had the highest repeatability value with tMHG (0.6360.760 , respectively in Saanen and in Czech White Shorthaired goats), and the following value was tMGG (0.501-0.721 respectively in Saanen and in Czech White Shorthaired goats). Repeatability of MGG and milking flow rate parameters were lower than in the previous ones $(0.165$ and 0.184 , respectively with HMF and DMFG in Czech White Shorthaired goats and 0.433-0.468 in Saanen goats). Phenotypic correlations of tMGG with $\mathrm{HMHG}$ and HMF with DMHG were very high and positive for both breeds $(\mathrm{P}<0.01)$. By comparison with our results, Peris et al. (1999) reported that milk yield correlated with milking time $(r=0.69 ; P<0.005$ in Murciano-Granadina goats) and Ilahi et al. (1999) determined correlations between the daily milk production and maximum flow rate ( $r=0.42$ in Alpine goat breed).

Assessing the relationship between the indicators of electrical conductivity of milk, the strongest correlation coefficients were estimated between ELMAX and ELHMF (0.892 and 0.933, respectively in Czech White Shorthaired and in Saanen goats). Very high and positive correlations between ELST

TABLE 3. Correlation coefficients among milk yield, milking duration, milking flow rate, electrical conductivity and SCC in Czech White Shorthaired (horizontal line) and in Saanen (vertical line) dairy goats

\begin{tabular}{l|l|l|l|l|l|l|l|l|l|l|l|l|l|}
\hline & SCClog10 & MGG & tMGG & tMHG & HMF & DMHG & ELAP & ELAD & ELMAX & ELMNG & ELHMF & ELST & ELND \\
\hline $\begin{array}{l}\text { SCClog } \\
10\end{array}$ & 1 & $0.192^{* *}$ & $0.162^{* *}$ & $0.118^{*}$ & 0.092 & $0.118^{*}$ & 0.093 & $0.142^{*}$ & $0.267^{* *}$ & $0.279^{* *}$ & $0.290^{* *}$ & $0.270^{* *}$ & $0.248^{* *}$ \\
\hline MGG & 0.079 & 1 & $0.725^{* *}$ & $0.760^{* *}$ & $0.184^{* *}$ & $0.165^{* *}$ & 0.085 & -0.031 & $0.136^{*}$ & -0.039 & -0.003 & 0.097 & $0.143^{*}$ \\
\hline tMGG & 0.061 & $0.501^{* *}$ & 1 & $0.916^{* *}$ & 0.081 & $-0.370^{* *}$ & 0.006 & -0.148 & 0.081 & 0.108 & -0.021 & 0.108 & $0.209^{* *}$ \\
\hline tMHG & -0.008 & $0.636^{* *}$ & $0.903^{* *}$ & 1 & $-0268^{* *}$ & $-0.392^{* *}$ & 0.051 & $-0.143^{*}$ & $0.124^{*}$ & -0.075 & 0.022 & 0.020 & $0.150^{* *}$ \\
\hline HMF & 0.129 & $0.433^{* *}$ & $-0.460^{* *}$ & $-0.464^{* *}$ & 1 & $0.878^{* *}$ & $0.162^{* *}$ & 0.050 & -0.015 & 0.064 & 0.097 & -0.003 & $-0.125^{*}$ \\
\hline DMHG & 0.081 & $0.468^{* *}$ & $-0.489^{* *}$ & $-0.524^{* *}$ & $0.909^{* *}$ & 1 & 0.120 & 0.028 & -0.028 & 0.090 & 0.038 & -0.030 & $-0.136^{*}$ \\
\hline ELAP & $0.237^{* *}$ & $0.140^{*}$ & 0.045 & 0.017 & 0.123 & -0.036 & 1 & $0.196^{* *}$ & $0.401^{* *}$ & $-0.137^{*}$ & $0.403^{* *}$ & -0.014 & -0.011 \\
\hline ELAD & $0.223^{* *}$ & 0.015 & $0.153^{*}$ & -0.002 & -0.036 & -0.026 & $0.332^{* *}$ & 1 & $-0.430^{* *}$ & -0.075 & $-0.290^{* *}$ & -0.072 & -0.129 \\
\hline ELMAX & $0.321^{* *}$ & 0.043 & $-0.148^{* *}$ & $-0.145^{*}$ & -0.104 & $-0.139^{*}$ & $0.403^{* *}$ & 0.009 & 1 & -0.075 & $0.892^{* *}$ & 0.129 & $0.185^{*}$ \\
\hline ELMNG & $0.308^{* *}$ & 0.100 & $0.506^{* *}$ & $0.225^{* *}$ & $-0.152^{*}$ & $-0.172^{* *}$ & 0.001 & $0.299^{* *}$ & 0.078 & 1 & -0.041 & 0.121 & 0.079 \\
\hline ELHMF & $0.406^{* *}$ & $0.133^{*}$ & $-0.183^{*}$ & $-0.170^{*}$ & -0.002 & -0.057 & $0.385^{* *}$ & -0.001 & $0.933^{* *}$ & 0.108 & 1 & 0.073 & 0.088 \\
\hline ELST & $0.314^{* *}$ & $0.320^{* *}$ & -0.055 & -0.108 & $0.429^{* *}$ & $0.180^{*}$ & $0.226^{* *}$ & $0.114^{*}$ & $0.177^{*}$ & $0.248^{* *}$ & $0.267^{* *}$ & 1 & $0.882^{* *}$ \\
\hline ELND & $0.400^{* *}$ & $0.316^{* *}$ & $0.209^{* *}$ & $0.158^{* *}$ & 0.125 & -0.102 & $0.369^{* *}$ & 0.084 & $0.218^{* *}$ & $0.297^{* *}$ & $0.231^{* *}$ & $0.741^{*}$ & 1 \\
\hline
\end{tabular}

${ }^{*} \mathrm{P}<0.05 ;{ }^{* *} \mathrm{P}<0.01$ 
TABLE 4. Effect of bimodality of milk flow curve in Czech White Shorthaired dairy goats

\begin{tabular}{l|l|l|l|l|l}
\hline \multirow{2}{*}{ Breed } & Bimodality of milk flow curves & \multicolumn{2}{|c|}{ MGG } & \multicolumn{2}{c}{ SCC } \\
\cline { 3 - 6 } & & M & SE & M & SE \\
\hline \multirow{2}{*}{ Czech White Shorthaired } & Normal curve & $1.586^{*}$ & 0.0058 & $6.175^{*}$ & 0.034 \\
\cline { 2 - 6 } & Bimodal curve & 1.298 & 0.116 & 6.208 & 0.118 \\
\hline \multirow{2}{*}{ Saanen } & Normal curve & $1.460^{*}$ & 0.101 & $6.002^{*}$ & 0.072 \\
\cline { 2 - 6 } & Bimodal curve & 1.329 & 0.083 & 6.083 & 0.061 \\
\hline
\end{tabular}

${ }^{*} \mathrm{P}<0.05$

and ELND, while moderate positive correlations between ELMAX and ELAP were estimated in both breeds. There were differences in the results of correlation analysis of electrical conductivity parameters between Czech White Shorthaired and Saanen goats. Czech White Shorthaired goats had moderate significant positive correlations between ELAD and ELMAX, ELAP and ELHMF $(P<0.01)$ which were not determined in Saanen goats. Saanen goats had a significant positive ELAP correlation between ELAD and ELND (0.332 and 0.369, respectively) which was not the case in Czech White Shorthaired goats.

In the present study, the bimodality of milk flow (Table 4) was determined in $9.69 \%$ goats $(10.43 \%$ in Czech White Shorthaired goat breed and in $6.78 \%$ in Saanen goat breed, $\mathrm{P}<0.01$ ). Boselli et al. (2016) reported higher results of bimodality (17.7\%). In study, comprising 3 goat breeds (Alpine, Maltese and Saanen), they reported the bimodality of 20.45 $\%, 18.81 \%$ and $14.07 \%$, respectively. On contrary, Zucali et al. (2019) estimated that the frequency of bimodal curves was very low (0.83\% on average) in the Alpine goat breed. We determined that MGG was higher $(\mathrm{P}<0.01)$ in normal milk flow curve from $0.131 \mathrm{~kg}$ (Saanen goat breed) to $0.288 \mathrm{~kg}$ (Czech White Shorthaired goat breed) compared to bimodal milk flow curve. In the present study a slight but significant $(P<0.01)$ SCC increase was indicated (0.033-0.081) in goats with bimodal milk flow curve. No bibliographic references were found in respect to the goats. In case of cows, Samoré et al. (2011) observed a $10.11 \%$ lower milk yield and $4.12 \%$ higher SCC in cows with bimodal milk flow curve compared to normal milk flow curve.

\section{Conclusions}

The present study investigated the parameters for milk yield, milking duration, milking flow rate, electrical conductivity and SCC in Czech White Shorthaired and Saanen goats. The analysis of the parameters showed the significant mean differences between the breeds $(\mathrm{P}<0.05)$. Phenotypic correlations of MGG with $\mathrm{TMHG}$ and $\mathrm{AMGG}$ were high, mean while those of tMGG with $\mathrm{TMHG}$ and HMF with DMHG were very high and positive for both breeds $(\mathrm{P}<0.01)$. The significant positive SCC correlation with almost all (except ELAP) investigated indicators of electrical conductivity suggest that it should be also one of the diagnostic methods for mastitis detection. Electrical conductivity equipment during milking may improve mastitis detection and thus improve udder health of goats.

Our findings indicated that bimodality in milk flow of goats is associated with milk yield decrease and SCC log 10 increase $(P<0.05)$, and supports the hypothesis of the unprofitable effect of bimodality on goat health and should be avoided during milking. 


\section{Povezanost muznih karakteristika i broja somatskih stanica s električnom provodljivosti kozjeg mlijeka tijekom različitih faza} mužnje

\section{Sažetak}

Cilj ove studije bio je procijeniti odnos muznih karakteristika i broja somatskih stanica (SCC) s električnom provodljivosti kozjeg mlijeka tijekom različitih faza mužnje. Istraživanje je provedeno u stadu pasmina češka bijela kratkodlaka i sanska koza $(n=323)$ uz pomoć elektroničkog mjerača protoka mlijeka LactoCorder ${ }^{\circledR}$. Količina mlijeka, trajanje mužnje, brzina protoka pri mužnji i električna provodljivost mlijeka u različitim fazama mužnje pokazali su značajne razlike između pasmina. Gotovo svi (osim ELAP) ispitivani pokazatelji električne provodljivosti pokazali su značajnu pozitivnu povezanost s brojem somatskih stanica. Bimodalnost protoka mlijeka utvrđena je kod 9,69 \% koza i povezana je sa smanjenjem prinosa mlijeka i porastom broja somatskih stanica $(\mathrm{P}<0,05)$. Rezultati potvrđuju da su podaci krivulje protoka mlijeka dobar alat za kontrolu muznih karakteristika, za predviđanje prevalencije mastitisa te tako za poboljšanje zdravlja vimena koza.

\section{Ključne riječi: koza, električna vodljivost, bimodalnost, krivulja protoka mlijeka}

\section{References}

1. Amin, A.A. (2020): Random regression animal models for genetic evaluation of test-day milk yield and milking duration in Saudi dairy goats. Indian Journal of Animal Research. https://doi.org/10.18805/ijar.B-988.

2. Bašić, Z., Džidić, A., Kostelić, A. (2009): The effect of prestimulation on milking characteristics during machine milking of goat. Mljekarstvo 59 (2), 83-87.

3. Borghese, A., Boselli, C., Rosati, R. (2013): Lactation curve and milk flow. Buffalo Bulletin 32, 334-350.

4. Boselli, C., Caria, M., Giangolini, G., Giacinti, G., Giontella, D., Murgia, L.. Pazzona, A., Amatiste, S., Rosati, R (2016): Curve di emissione del latte registrate in allevamenti caprini della regione lazio XXII Congresso Nazionale S.I.P.A.O.C. Società Italiana di patologia e allevamento degli ovini e dei caprini 13 - 16 Settembre.

5. Boselli, C., Giangolini G., Filippetti F., Giacinti G., Amatiste, S. (2009): Milk flow traits during lactation in Saanen goats raised in Latium region. XVII Intenational Congress of Mediterranean Federation of Health and Production of Ruminant, May 27-30, Perugia - Italy.

6. Ciappesoni, G., Přibyl, J., Milerski, M., Mareš, V. (2004): Factors affecting goat milk yield and its composition. Czech Journal of Animal Science 49, 465-473. https://doi.org/10.17221/4333-CJAS

7. Diaz, J.R., Romero, G., Muelas, R., Alejandro, M., Peris, C. (2012): Effect of intramammary infection on milk electrical conductivity in Murciano-Granadina goats. Journal of Dairy Science 95, 718-726. https://doi.org/10.3168/jds.2011-4698
8. Diaz, J.R., Romero, G., Muelas, R., Sendra, E., Pantoja, J. C. F., Paredes, C. (2011): Analysis of the influence of variation factors on electrical conductivity of milk in Murciano-Granadina goats. Journal of Dairy Science 94, 3385-3394. https://doi.org/10.3168/jds.2011-4187

9. Dzidic, A., Macuhova, J., Bruckmaier, R.M. (2004): Effects of cleaning duration and water temperature on oxytocin release and milk removal in an automatic milking system. Journal of Dairy Science 87, 4163-4169. https://doi.org/10.3168/jds.S0022-0302(04)73559-6

10. Fernández, N., Martí, J.V., Rodríguez, M., Peris, C., Balasch, S. (2019): Machine milking parameters for MurcianoGranadina breed goats. Journal of Dairy Science 103, 507-513. https://doi.org/10.3168/jds.2019-16446

11. Gautam, L., Waiz, H.A., Nagda, R.K. (2020): Significance of environmental influences on average saily milk traits of Sirohi goats in their native tract. Indian Journal of Animal Research. https://doi.org/10.18805/ijar.B-3834

12. Guney, O., Torun, O., Ozuyanik, O., Darcan, N. (2006): Milk production, reproductive and growth performances of Damascus goats under Northern Cyprus conditions. Journal of Small Ruminant Research 65, 176-179. https://doi.org/10.1016/j.smallrumres.2005.07.026

13. Hinckley, L.S., Williams, L.F. (1981): Diagnosis of mastitis in goats. Veterinary Medicine Small Animal Clinics 76, 711-712. 
14. Ilahi, H., Chastin, P., Bouvier, F., Arhainx, J., Ricard, E., Manfredi, E. (1999): Milking characteristics of dairy goats. Small Ruminant Research 34, 97-102. https://doi.org/10.1016/S0921-4488(99)00057-7

15. Ilahi, H., Manfredi, E., Chastin, P., Monod, P., Elsen, J.M., Le Roy, P. (2000): Genetic variability in milking speed of dairy goats. Genetical Research Cambridge 75, 315-319. https://doi.org/10.1017/S001667230000450X

16. Kendall, P.E., Nielsen, P.P., Webster, J.R., Verkerk, G.A., Littlejohn, R.P. (2009): The effects of providing shade to lactating dairy cows in a temperate climate. Livestock Science 103, 148-157. https://doi.org/10.1016/j.livsci.2006.02.004

17. Leitner, G., Silanikove, N., Merin, U. (2008): Estimate of milk and curd yield loss of sheep and goats with intramammary infection and its relation to somatic cell count. Small Ruminant Researh 74, 221-225. https://doi.org/10.1016/j.smallrumres.2007.02.009

18. Mioč, B., Prpić, Z., Vnučec, I., Barać, Z., Sušić, V., Samaržija, D., Pavić, V. (2008): Factors affecting goat milk yield and composition. Mljekarstvo 58, 305-313.

19. Morgante, M., Brajon, G., Cuteri, V., Perfetti, M.G., Di Maurizio, V., Ranucci, S. (2000): Somatic cell counts in goat milk: comparison among four different methods. Proceedings of the $7^{\text {th }}$ International Conference on Goats, Tours, France, 765-766.

20. Norris, D., Ngambi, J.W., Benyi, K., Mbajiorgu, C.A. (2011): Milk production of three exotic dairy goat genotypes in Limpopo province, South Africa. Asian Journal of Animal and Veterinary Advances 6, 274-281. https://doi.org/10.3923/ajava.2011.274.281

21. Paape, M.J. (2000): Situation regarding the legal limit for somatic cell counts for goats in the United States. Proceedings of the $7^{\text {th }}$ International Conference on Goats, Tours, France, 755-756.

22. Palhière, I., Larroque, H., Clément, V., Tosser-Klopp G., Rupp, R. (2014): Genetic parameters and QTL detection for milking speed in dairy alpine and Saanen goats. $10^{\text {th }}$ World Congress on Genetics Applied to Livestock Production. Vancouver, BC, Canada.

23. Peris, S., Caja, G., Such, X. (1999): Relationships between udder and milking traits in Murciano-Granadina dairy goats. Small Ruminant Research 33, 171-179. https://doi.org/10.1016/S0921-4488(99)00017-6
24. Romero, G., Pantoja, J.C.F., Sendra, E., Peris, C., Diaz, J.R. (2012): Analysis of the electrical conductivity in milking fractions as a mean for detecting and characterizing mastitis in goats. Small Ruminant Research 107, 157-163. https://doi.org/10.1016/j.smallrumres.2012.05.001

25. Samoré, A.B., Román-Ponce, S.I., Vacirca, F., Frigo, E., Canavesi, F., Bagnato, A., Maltecca C. (2011): Bimodality and the genetics of milk flow traits in the Italian Holstein-Friesian breed. Journal of Dairy Science 94 (8), 4081-4089. https://doi.org/10.3168/jds.2010-3611

26. Silanikove, N., Leitner, G., Merin, U., Prosser, C.G. (2010): Recent advances in exploiting goat's milk: quality, safety and production aspects. Small Ruminant Research 89, 110-124. https://doi.org/10.1016/j.smallrumres.2009.12.033

27. Tangorra, F.M., Zaninelli, M., Costa, A., Agazzi, A., Savoini, G. (2010): Milk electrical conductivity and mastitis status in dairy goats: results from a pilot study. Small Ruminant Research 90, 109-113. https://doi.org/10.1016/j.smallrumres.2010.02.006

28. Yarabbi, H., Mortazavi, A., Mehraban, M., Sepehri, N. (2014): Effect of somatic cells on the physic- chemical and microbial properties of raw milk in different seasons. International Journal of Plant, Animal and Environmental Sciences 4 (3), 289-298.

29. Ying, C.H., Yang, C.H.B., Hsu, J.T. (2004): Relationship of somatic cell count, physical, chemical and enzymatic properties to the bacterial standard plate count in different breeds of dairy goats. Asian-Australasian Journal of Animal Sciences 17, 554-559. https://doi.org/10.5713/ajas.2004.554

30. Zaninelli, M., Rossi, L., Costa, A., Tangorra, F.M., Agazzi, A., Savoini, G. (2015): Monitoraggio dello stato di salute delle capre attraverso l'analisi on-line della conducibilità elettrica del latte. Large Animal Review 21, 81-86.

31. Zazharska, N., Boyko, O., Brygadyrenko, V. (2018): Influence of diet on the productivity and characteristics of goat milk. Indian Journal of Animal Research 52 (5), 711-717.

32. Zucali, M., Tamburini, A., Sandrucci, A., Gislon, G., Bava, L. (2019): Effect of vacuum level on milk flow and vacuum stability in Alpine goat. Small Ruminant Research 171, 1-7. https://doi.org/10.1016/j.smallrumres.2018.11.025 